\title{
Potential of ethnobotanical medicinal plants used by Malayali tribes in Yercaud hills, Eastern ghats of Tamil Nadu, India
}

\author{
Rekka Raja* \\ Department of Botany, Kongunadu Arts and Science College (Autonomous), GN Mills Post, \\ Coimbatore-641029 (Tamil Nadu), India \\ Nirubama Kumar \\ Department of Biochemistry, Kongunadu Arts and Science College (Autonomous), GN Mills \\ Post, Coimbatore-641029 (Tamil Nadu), India \\ Moorthy Duraisamy \\ Department of Botany, Kongunadu Arts and Science College (Autonomous), GN Mills Post, \\ Coimbatore-641029 (Tamil Nadu), India \\ ${ }^{*}$ Corresponding Author: rekkar_bo@kongunaducollege.ac.in
}

\section{How to Cite}

Raja R. et al. (2020). Potential of ethnobotanical medicinal plants used by Malayali tribes in Yercaud hills, Eastern ghats of Tamil Nadu, India. Journal of Applied and Natural Science, 12(4):560 - 567. https://doi.org/10.31018/jans.v12i4.2393

\begin{abstract}
Ethnobotanical knowledge plays an important role in therapeutic beneficial by traditional people of the Yercaud hills, Eastem ghats of the State Tamil Nadu. This current study focused on documentation of medicinal plants used to treat several ailments. Enlightenment of medicinal plants data was gathered from the Malayali tribes, using an integrated approach like botanical collections, group discussion and interviews with questionnaires in the year $2018-2019$. During the survey a total number of 40 ethnomedicinal plant species belonging to 38 genera and 25 families were documented. Traditional names of the plants by traditional healers and local community members were prepared as a checklist. The checklist of medicinal plants used by Malayali tribes are listed with botanical name, vernacular name, family, parts used, mode of preparation, mode of admiration and medicinal uses. We observed that the documented ethnomedicinal plants were commonly used to treating snakebite, earache, chest pain, body pain, lumbago, eczema, haemorrhoids, jaundice, dog bite, sprain, beetle bite, epididymitis, bone fracture, arthritis and painful menstruation. The results of this study showed that the tribal people still depended on medicinal plants in Yercaud Hills for treating various diseases. This would be a baseline data of medicinal plants for future research and potential development of novel drugs.
\end{abstract}

Keywords: Documentation, Eastern Ghats, Medicinal plants, Malayali tribes, Yercaud Hills

\section{INTRODUCTION}

The ethnomedicinal system and herbal medicine is a healing agent of chief importance in addressing health care problem of traditional communities (Tilahun and Moa, 2018). The therapeutically vital plants are known to be used by folkloric people to treat various diseases such as diabetes, dysentery, fever, headache, rheumatism, snakebite, cough and some as food and food additives (Tripuresh et al., 2019). A large helping of the world population, particularly in developing countries, depends on traditional medicine for the treatment of diseases and wounds. The World Health Organization reported that $80 \%$ of the world populations trust mainly on indigenous medicine and that the common of traditional therapies involve the use of plant extracts or their dynamic constituents (Fabricant and Farnsworth, 2001).
A tropical country like India having a rich diversity of medicinal plants formally recognizes nearly about 8,000 species with their medicinal value. Globally, about $85 \%$ of the traditional medicines used for primary health care are derived from plant parts uses with a great number of tribal people who are living in different geographic locations with various subsistence patterns (Abubacker et al., 2018 and Sathishkumar and Anbarasu, 2019). These tribal groups living in biodiversity-rich areas possess a wealth of knowledge on the utilization of medicinal plants to relive people from various diseases and illness without any side effects. Traditional medicine and ethnobotanical information can provide valuable clues for the selection, preparation and indications for the use of herbal formulation in the field of scientific research especially for the discovery of plant-based drugs. This traditional knowledge of 
medicinal plants handed over to generation to generation without any written document and also it has helped them to have a sense of responsibility in judicious utilization of the plant resources and also to conserve (Premkumar and Sundarrajan, 2018).

There is vast information on the use of indigenous medicinal plants in Yercaud over the last periods. In light of this, therefore, there is a high expectation of vast traditional knowledge of medicinal plant species in Yercaud hills due to the use of diverse plant species, variety of cultures, various languages, and views among the different ethnic groups in Yercaud. To our information, there are no data about the traditional medicinal plant knowledge and use by several local communities in Yercaud. Moreover, Yercaud is one of the experiencing dynamic changes in cultural norms and system, which renders the traditional and local knowledge of medicinal plants to be easily forgettable as most of the indigenous traditional knowledge is moved to the local community members orally. Therefore, the current study revealed to assess and document the medicinal plants use among the traditional healers and local community members in and around the Yercaud hills.

\section{MATERIALS AND METHODS}

The present investigation was undertaken to collect information from Malayali tribes on the use of medicinal plants from Yercaud Hills, Tamil Nadu. Fieldwork in tribal areas was the most important part of all ethnobo- tanical research. Before starting with fieldwork, preliminary information about the geographical area of study, its physiographical features, climate etc. were collected. A general idea about the tribal community was acquired from the publication of Malayali tribes. With the help of the Yercaud map (Fig. 1), the tribal hamlets to be visited were located. Means of conveyance and easiest route to each village from the research station were identified, and frequent field surveys were carried out in Yercaud hills in different seasons during 20142016. The information was accrued after discussions with sixty-three tribal persons, the village head, elderly persons and other local informants. Ethnobotanical data were collected using semi-structured interviews, group discussion, guided field walks, and observations with participants. Uses of plants as given by them were recorded and voucher specimens were also collected simultaneously, for authentication of information and future record through herbaria. The collected ethnomedicinal information was recorded on field notebooks and plants were identified using the Flora of the Presidency of Madras (Gamble and Fischer 1935) and Flora of Tamil Nadu-Carnatic (Mathew, 1983).

\section{RESULTS AND DISCUSSION}

The present exploration revealed that 40 plant species belonging to 38 genera of 25 families were used by Malayali tribes for treating various ailments like a snake bite, earache, chest pain, body pain, lumbago, eczema, haemorrhoids, jaundice, dog bite, sprain,

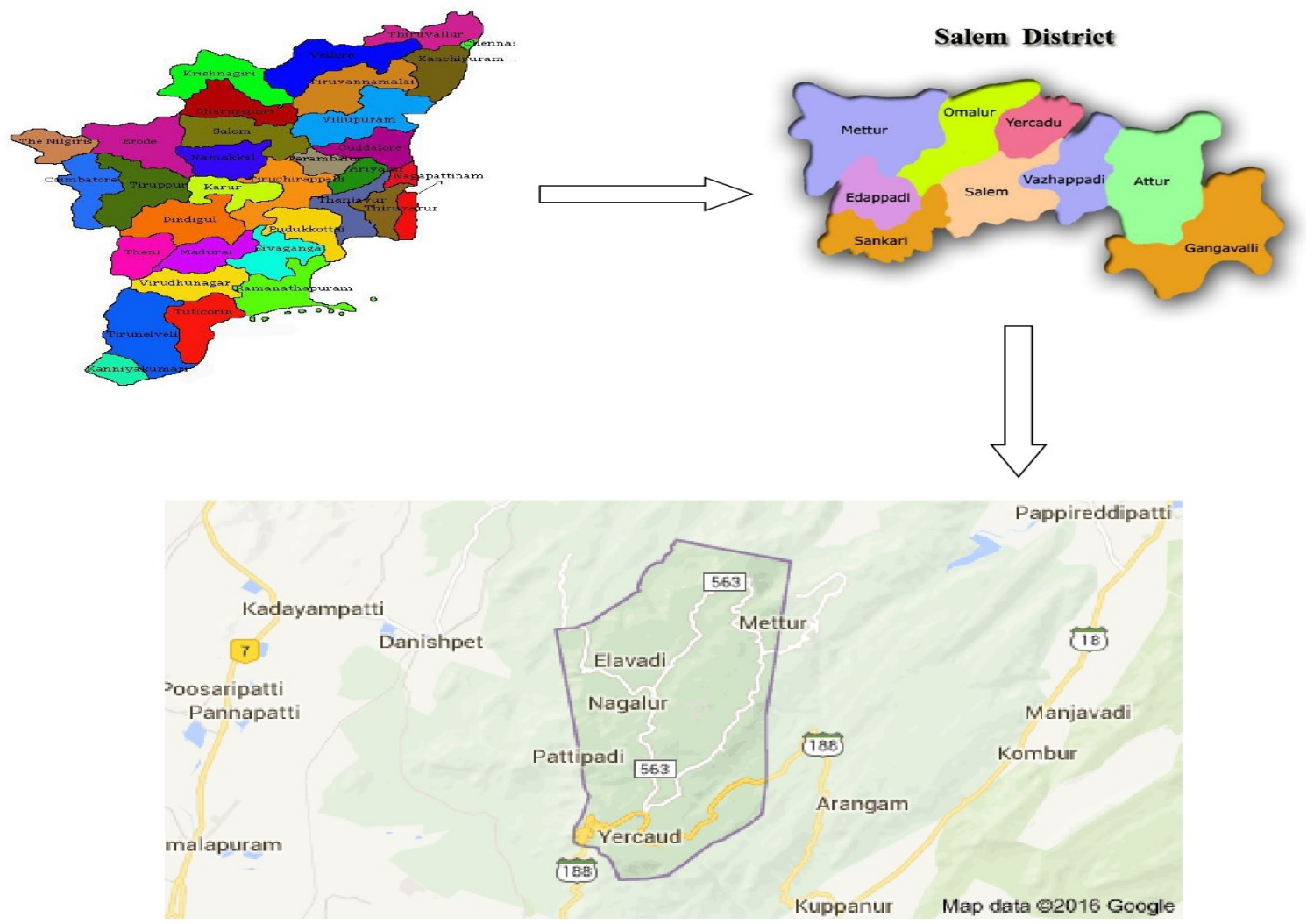

Fig. 1. Location of study area map showing in Yercaud hills. 
Raja R. et al. / J. Appl. \& Nat. Sci. 12(4): 560 - 567 (2020)

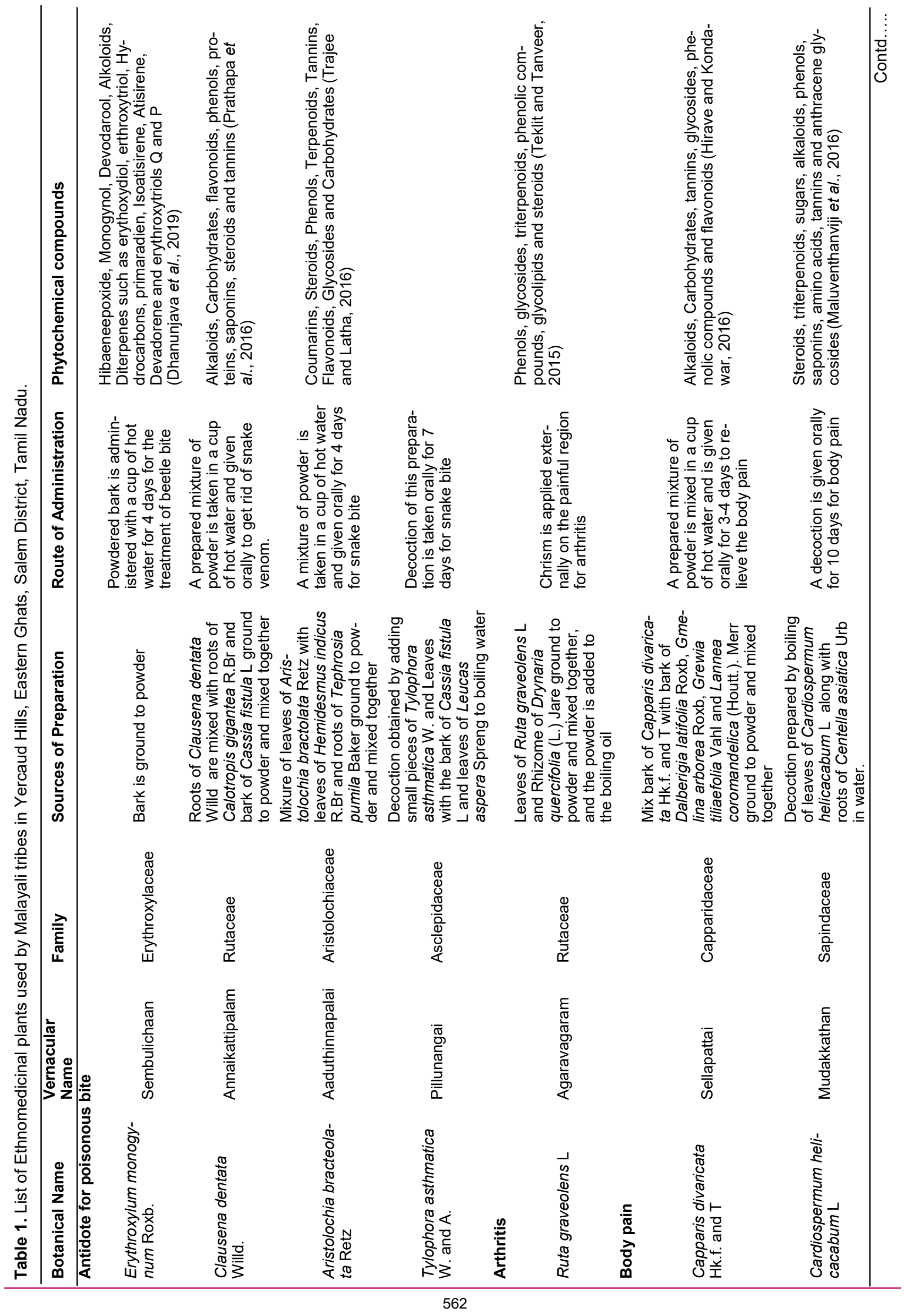


Raja R. et al. / J. Appl. \& Nat. Sci. 12(4): 560 - 567 (2020)

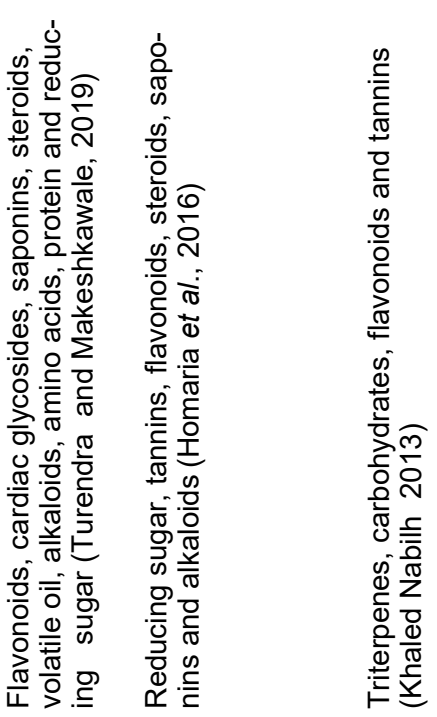

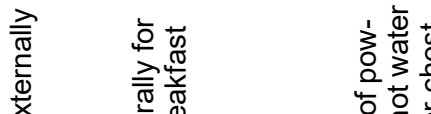

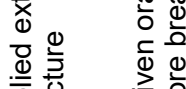

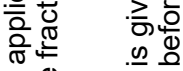

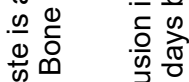

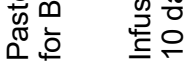

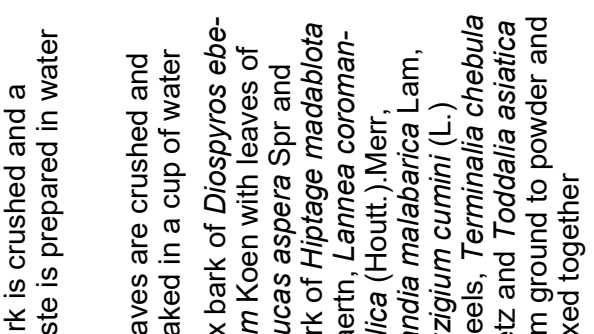

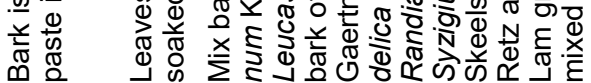

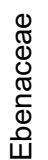

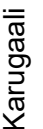

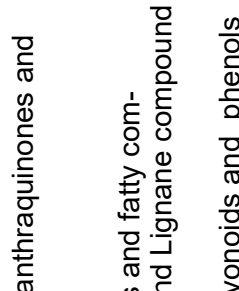

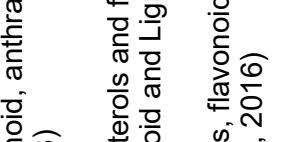

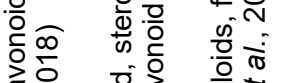

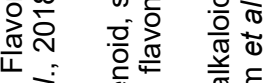

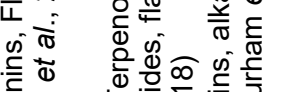

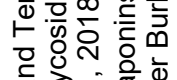

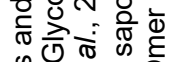

कण

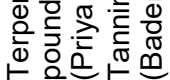

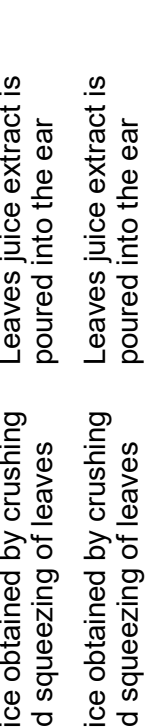

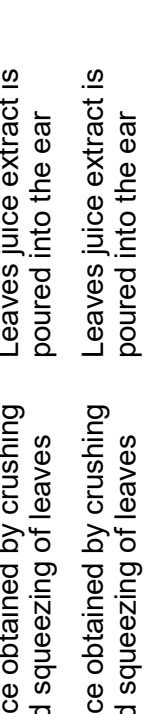

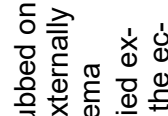

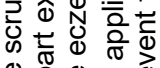

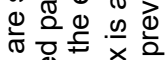

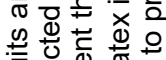

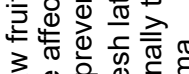

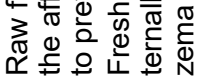

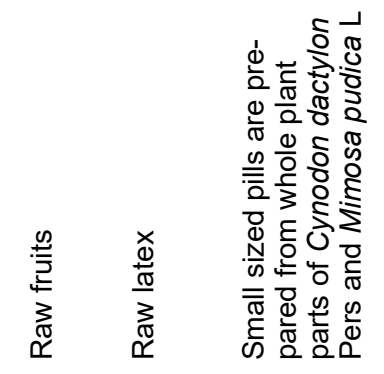
$\frac{\pi}{2} \frac{\pi}{0}$ है d

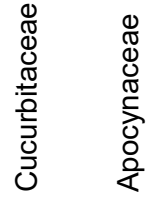

0
$\mathbb{\pi}$
$\mathbb{0}$
$\mathbb{0}$
0
0

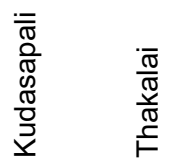

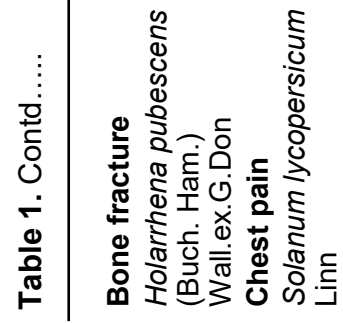

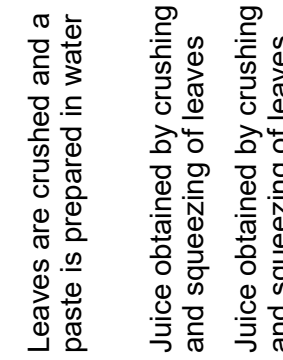

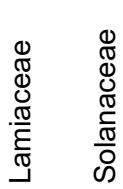

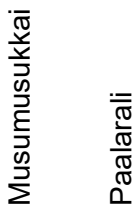

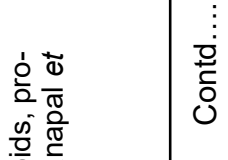

ำ 논

它

त्र

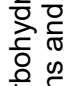

융.

다유.

응 응 का 응 으

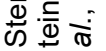

충

힝

츤 ญ

สั

흥

DO 焉合:

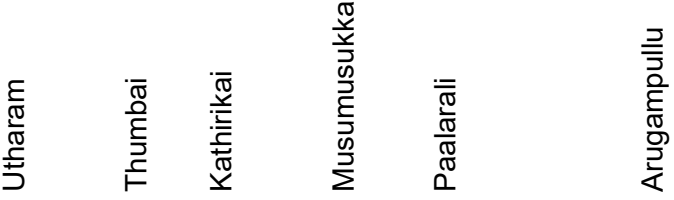

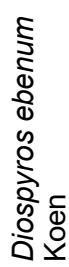

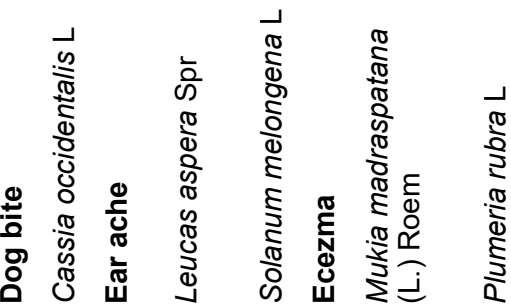

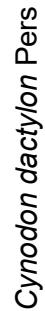


Raja R. et al. / J. Appl. \& Nat. Sci. 12(4): 560 - 567 (2020)

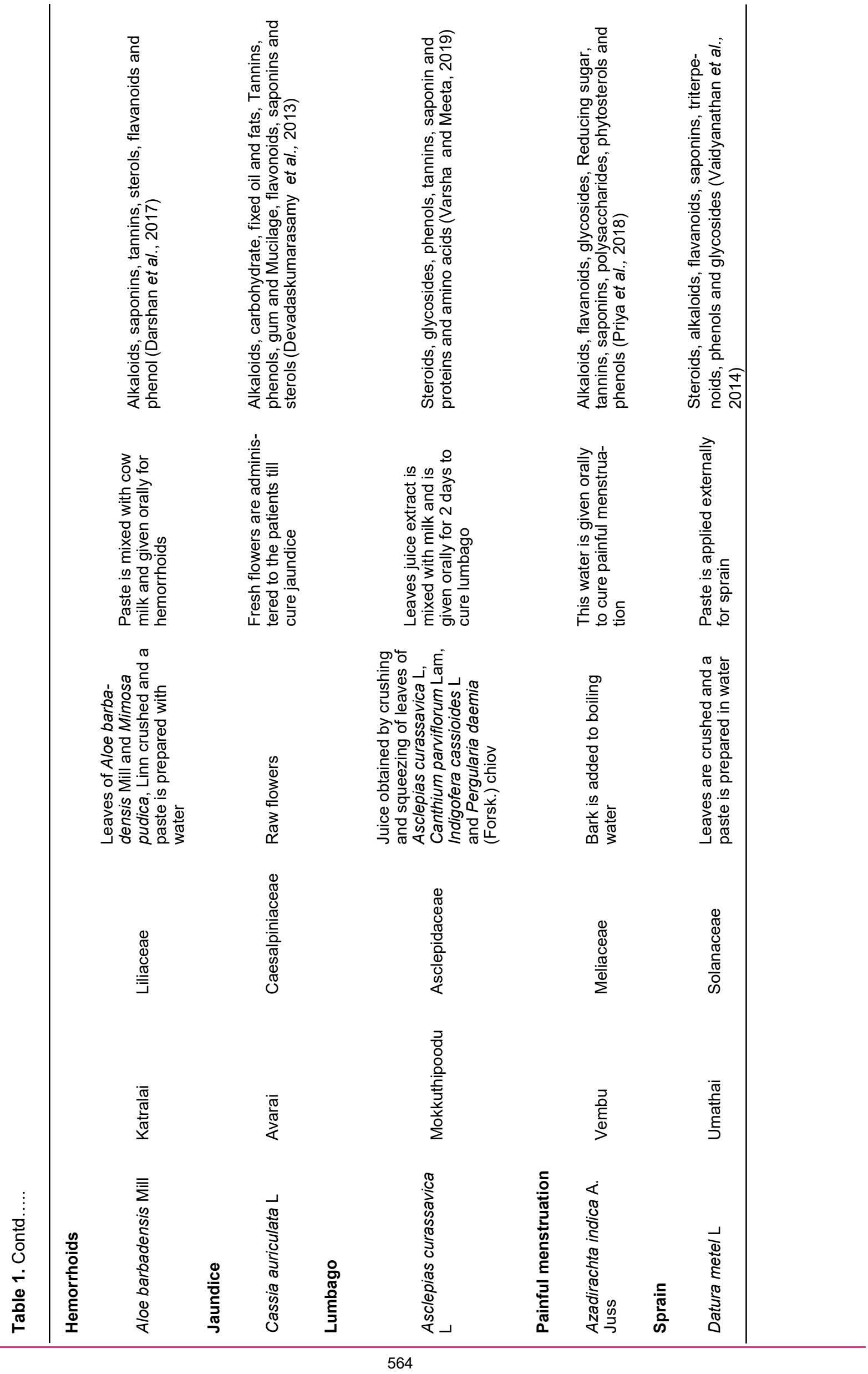




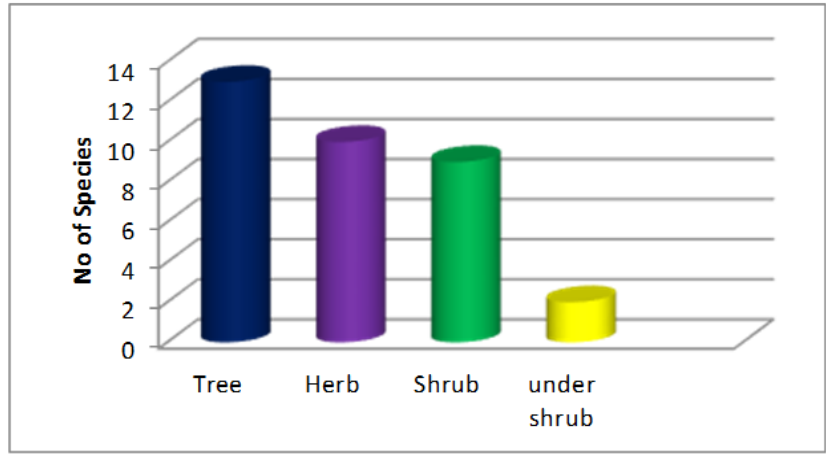

Fig. 2. Habit wise distrubution of recorded medicinal plants from Yercaud hills.

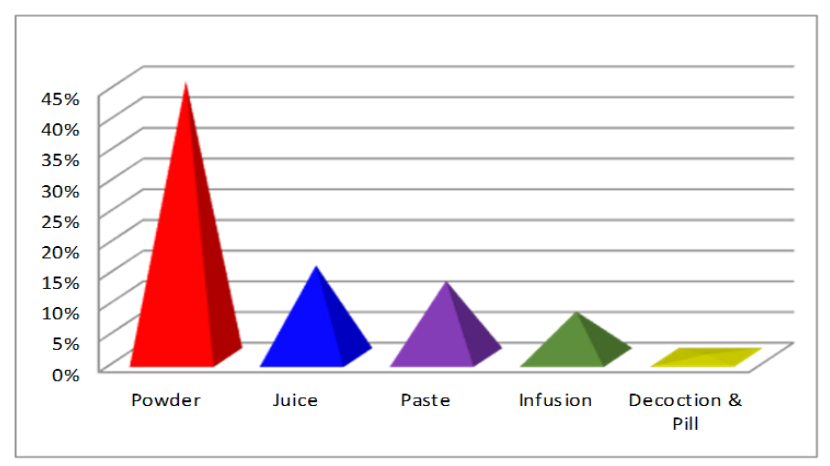

Fig. 4. Percentage of source of preparations used by Malayali Tribes for medicinal purpose.

beetle bite, epididymitis, bone fracture, arthritis and painful menstruation which are catalogued in Table 1.

The traditional healers prepared the herbal formulation by use of vastly tree species. Among the 40 species, tree (13 species), herb (10 species), shrub (9 species), climber (6 species) and undershrub (2 species) were recorded and are represented in Fig. 2. Savinaya et al. (2016) also reported the advantages of different tree species as the dominant herbal medicine source. This was also due to the existence of the evergreen type of forest where the floor is covered maximum with budding forms of evergreen tree species likewise tall trees that form a ceiling from the sun above. This ceiling keeps smaller plants from growing. The most dominant plant parts by Malayali tribes in the study were leaves (16 species) which are commonly used in herbal medicines because they are rich in bioactive secondary metabolites; and also, the leaves are the main photosynthetic organs and act as the storage for exudates which are against lethal entities and also medicinal benefits to the human body (Ahmad et al. 2014) followed by bark (13 species), and root (5 species) other parts with the low number are listed; whole plant parts (2 species) and fruit, flower, rhizome and latex (1 species each) are shown in Fig. 3.

Malayali tribes are used various mode of preparation from medicinally important plants included paste, decoction, powder, juice, infusion, pill, chrism and raw material for curing various ailments. In our study the plant products are consumed raw or in the form of powder (45\%), juice (15\%), infusion $(7.5 \%)$, decoction

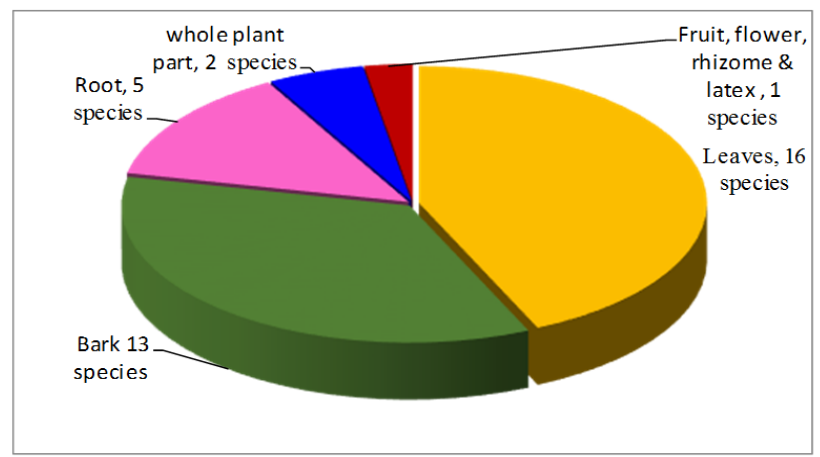

Fig. 3. Different types of plant parts used by Malayali tribes for medicine.

and pill $(0.5 \%)$ for oral treatment and paste $(12.5 \%)$ and chrism (0.5\%) when applied externally (Fig. 4). The Malayali traditional healers used more than one plant for the preparation of medicine in the treatment of various ailments. The frequent use of multiple plant remedies among the traditional healers could be attributed to the belief of collaborative effect where one plant could have a potentiating effect on the other (Giday et al. 2009). Polyherbal formulations are more effective to treat the diseases as compared to the single plant (Teklehymanot et al. 2007).

The medicinal uses of plants gathered in the study were compared with the previously published information from Yercaud hills (Udayan and Satheesh George, 2006, Kadaval and Dixit, 2009, Parthipan et al., 2011 and Senthilkumar et al., 2013) and also from Eastern Ghats of Tamil Nadu (Dhatchanamoorthy et al.2013, Salai Senthilkumar et al., 2014 and Vaidyanathan et al., 2014). The combination of herbals in our observation differed from the reports like Senthilkumar et al. (2013) who recorded that Malayali tribes in Yercaud hills used Calotropis giganeta for swellings, Cassia occidentalis for skin diseases, Cynodon dactyIon for kidney disorder Leucas aspera for fever and stomachache, and Ruta graveloens for dysentery. But in our observation, these plants were used for the treatment of snakebite, dog bite, epididymitis, chest pain and arthritis, respectively. Anjalam et al. (2016) reported that Malayali tribes in Kolli hills used Erytroxylum monogynum leaves paste which acted as antipetide and in our findings bark of Erytroxylum monogynum was used for the antidote for the poisonous bite. Soniya and Raju (2017) documented Azadirachta indica for liver ailments, Cardiosperum helicacabum for rheumatic pains, Cassia auriculata for heart discomforts and Datura metal for chronic ulcer and asthma were similar to our findings. In addition, many of the ethnomedicinal plants reported during the present investigation are scientifically proved for various biological activities (Maluventhanviji et al., 2016; Teklit and Tanveer, 2015; Hirave and Kondawar,2016; Prathapa Reddy et al., 2016; Trayee and Latha, 2016; Dhanunjava et al., 2019; Turendra and Maheshkawale, 2019). 


\section{Conclusion}

Medicinal plants that were traditionally used for different ailments in Yercaud hills by Malayali tribes in Tamil Nadu as well as all over the world contain a variety of chemical constituents and thus can be more effective and can play a significant role to cure different diseases and disorders. A comprehensive study is required to conserve these wild medicinal and aromatic plant species. Even though there is no existing database to deposit the documented traditional knowledge in the study area, elderly people of the local area were always satisfied with medicinal plants and their healing uses. It is, therefore, proposed that the traditional knowledge from the people should be documented along with quality photography. The documentation of this current study also supports the ethnomedicinal benefits, as stated in earlier studies.

\section{ACKNOWLEDGEMENTS}

I extend my special thanks to Mr. N. Thangaraju, I.F.S., District Forest Officer, Salem Division, Salem, to give permission to carry out my research work in Yercaud hills area. I express my gratitude to the local traditional healers in the Yearcaud hills for sharing their knowledge of herbal medicines.

\section{Conflict of interests}

The authors declare that they have no conflict of interests.

\section{REFERENCES}

1. Abubacker, M. N., Gurunathan, S., Ganapathy, G. and Prince, M. (2018). Survey of some ethno medicine used by tribal population in Nilgiri Hills, South India, American Journal of Ethnomedicine. 5(1): 1-7.

2. Ahmad, M., Sultana, S., Fazi-i-Hadi, S., Ben Hadda, T., Rashid, S., Zafar, M., Khan, M.A., Khan, M.P.Z. and Yaseen, G. (2014). An ethnobotanical study of medicinal plants in high mountainous region of chail valley (district Swat-Pakistan), J. Ethnobiol Ethnomed. 10: 36

3. Anjalam, A., Kalpana, S., Vijai, D. and Premalatha, S. (2016). Documentation of medicinal plants used by malayali tribes in Kolli Hills, International Journal of Advanced Research in Biological Science, 3(3): 101 - 107.

4. Bader Omer Burham. (2016). Phytochemical Screening and elemental analysis of Solanum melongena (Peels) from Albaha area (KSA), Asian Journal of Biochemmical and Pharmaceutical Research. 2(6): 113 - 122.

5. Darshan Dharajiya., Nalin pagi., Hitesh Jasani and Payal Patel. (2017). Antimicrobial activity and phytochemical screening of Aloe vera (Aloe barbadensis Miller), International Journal of Current Microbiology and Applied Science. 6(3): 2152-2162.

6. DevadosKumarasamy Raja., Nattanmai Sudararaman Jeganathan and Rajappan Manavalan. (2013). In vitro antimicrobial activity and phytochemcial analysis of Cassia auriculata Linn, International Current Pharmaceutical Journal. 2(6): 105-108.

7. Dhanapal Venkatachalam., Samuel Thavamani B and Muddukrishniah. (2018). Pharmocognostical and phyto- chemical evaluation of leaf of Plumeria rubra, World Journal of Pharmaceutical Research., 7 (4): 605-616.

8. Dhanapal Venkatachalam., Samuel Thavamani, B., Muddukrishniah, K., Suganyavijayan and Vinod, K.R. (2017). Antimicrobial activity and phytochemical analysis of aerial parts of Cynodon ndactylon, International Journal of Academic Research and Development., 3 (3): 116-121.

9. Dhanunjaya Kumar, C., Anitha, S., Varalakshmi, P., Dowlathabad, and Muralidhara Rao. (2019). Evaluation of Potential phytochemical and phytopharmacological activities of Erythroxylum mononogynum Roxb, Biosciences Biotechnology Research Asia.,16 (2): 441-449.

10.Dhatchanamoorthy, N., Ashok kumar, N and Karthik, K. (2013). Ethnomedicinal plants used by Irular tribes in Javadhu hills of Southern Eastern Ghats, Tamil Nadu, India, International Journal of Current Research and Development, 2(1): $31-37$.

11.Fabricant, DS. and Farnsworth, NR. (2001). The Value of Plants Used in Traditional Medicine for Drug Discovery. Environmental Health Perspectives., 109: 69-75.

12.Gamble, J.S. and Fischer C.E.C. (1935). Flora of Presidency of Madras, London (Issued in II part: 1-7 By Gamble, 8-11 by Fischer). 1-3, Calcutta.

13.Giday, M., Asfaw, Z. and Woldu, Z. (2009). Medicinal plants of the Meinit ethnic group of Ethiopia, An ethnobotanical study, J Ethopharmacol.,124: 513 - 521.

14.Gomathy, G., Vijay, T., Sarumathy, K., Gunasekaran, S. and Palani, S. (2012). Phytochemical screening and GCMS analysis of Mukia maderaspatana (L.) leaves, Journal of Applied Pharmaceutical Science., 2(2): 104-106.

15. Hirave, R.V. and Kondawar, M.S. (2016). Anticancer activity of Capparis divericata Lam leaves extract, International Research Journal of Pharmacy. 7(8): pp 13-15.

16. Homaria Afreen, Toufiq-UI Amin Md. Siddiqul Islam, Salma Parvin and Rayhanus. (2016). In vitro phytochemical analysis and cytotoxic assay of leaves of Solanum lycopersicum Linn by brine shrimp bioassay, Journal of Innovations in Pharmaceuticals and Biological Sciences., 3 (3): 81-85.

17.Kadavul, K., Dixit,A.K. (2009). Ethnomedicinal studies of the woody species of Kalayaran and Shervarayan hills, Eastern Ghats, Tamil Nadu, India, Journal of Traditional Knowledge., 8 (4): 592-597.

18.Khaled NabilhRashed. (2013). Antioxidant activity from Diospyros ebenum stem extracts and phytochemical profile, Journal of Applied and Industrial Science., 1 (2): 70 - 72.

19.Maluventhanviji, Mani Sathiya and Sangu Murugesan (2016). Phytochemical analysis and antibacterial activity of medicinal plant Cardiospermum helicacabum Linn, Pharmacology online., 2: 445-456.

20.Mathew, K.W. (1983). Flora of Tamil Nadu Carnatic, the Rapinat Herbarium, Tiruchirapalli, India.

21.NnamaTochukwu., IlodibeChigozie., Okeke Somandina., Ikpeze., S.C. and Ozumba, O.G. (2018). Phytochemical and acute toxicity study of Cassia occidentails leaf extract in Albino Wister Rats, EC Clinicaal and Experimental Anatomy., 1 (3): 118-123.

22.Parthipan, M., Aravindhan,V. and Rajendran, A. (2011). Medico-botanical study of Yercaud hills in the Eastern Ghats of Tamil Nadu, India, Anc Sci Life.,30(4): 104-109.

23.Prathapa Reddy, M., Rama Rao, V., Shantha, T.R, Kishore kumar, R., Shiddamallayya, N. and Sulochana Bhat. (2016) Phytochemical analysis and thin layer chromatography of Clausens dentate (Willd) Roem, World Journal of Pharmacy and Pharmaceutical Sciences., 5(9): 
1706-1716.

24.Premkumar and sundarrajan. (2018). Medicinal Plants used by the Malayali Tribe of Servarayan Hills, Yercaud, Salem District, Tamil Nadu, India International Journal of Science and Research, 7: :956-961

25.Priya, R., Nirmala, M., Shankar, T. and Malarvizhi, A. (2018). Phytochemical compounds of Leucas aspera L, Pharmacological Benefits of Natural Products., 2: 19-35.

26.Salai Senthilkumar, M.S., Vaidyanathan, D., Sivakumar, D. and Ghouse Basha., M. (2014). Diversity of ethnomedicinal plants used by Malayali tribals in Yelagiri hills of Eastern ghats, Tamil Nadu, India, Asian Journal of Plant Sciences and Research., 4 (1): 69-80.

27.Sathishkumar and Anbarasu. (2019). Ethnomedicinal plants of Gopalswamy Hills, Western Ghats, Coimbatore District, Tamil Nadu, International Journal of Plant, Animal and Environmental Science., 9(1): 6-12.

28.Savinaya, M.S., Sangamesh, S., Patil, Narayana, J. and Krishna,V. (2016). Traditional medicine and diversity of medicinal plants in Sharavathi valley region of central Western Ghats, International Journal of Herbal Medicine., 4(6): 124-130.

29.Senthilkumar, K., Aravindhan, V., and Rajendran, A. (2013). Ethnobotanical Survey of Medicinal Plants used by Malayali Tribes in Yercaud Hills of Eastern Ghats, India, Journal of Natural Remedies, 13 (2): 118-132.

30.Senthilkumar, K., Aravindhan,V. and Rajendran, A. (2013). Ethnobotanical Survey of Medicinal Plants used by Malayali Tribes in Yercaud Hills of Eastern Ghats, India, Journal of Natural Remedies.,13 (2): 118-132.

31.Soniya,S. and Raju, K. (2017). Traditional herbal remedies the tribes of Malayali in Shervarayan Hills (Yercaud), Salem District, Tamil Nadu, Int. Journal of Engineering Research and Application., 7(11): 86-91.

32.Teklehymanot, T., Giday, M., Medhin, G. and Mekonnen, G. (2007). Knowledge and use of medicinal plants by people around Debre Libanos monastery in Ethiopia, $J$ Etho- pharmacol.,111: 271 - 283.

33.Teklit Gebregiorgis Amabye and Tanveer Mahamadail Shalkh. (2015). Phytochemical Screening and Evaluation of antibacterial activity of Ruta graveolens L. - a medicinal plant around Mekelle, Tigray, Ethiopia, Natural Products and Research, 3 (6): 2-4.

34. Tilahun Tolossa Jimma and Moa Me gersa. (2018). Ehanobotanical studies of medicinal plants used to treat human diseases in Berbere District, Bale zone of Oromia Regional state South East Ethopia, Evidence based Complementary and Alternative medicine, 1-6.https://doi.or $\mathrm{g} / 10.1155 / 2018 / 8602945$.

35.Trayee Sarar Das, R and Latha Agastian P. (2016). Evaluation of Aristolochia bracteolate Linn for antimicrobial activity, Glucosidase inhibition and its phytochemical constituents, Asian Journal of Pharmaceutical Research, 9(1): 102-107.

36. Tripuresh Dwivedi., Chandra Kanta., Lalit Raj Singh and Ishwar Prakash Sharma. (2019). A list of some important medicinal plants with their medicinal uses from Himalayan State Uttarakhand, India, JMPS, 7(2): 106-116

37.Turendra Lilhare and Mahesh Kawale. (2019). Pharmacognostic and phytochemical studies on Holarrhena antidysenterica (Roth) Wall. Ex. A. Dc. Global Journal of Bioscience and Biotechnology., 8(2): 162-167.

38.Udayan, PS., Satheesh George, K.V., Tushar and Indira Balachandran. (2006). Medicinal Plants used by the Malayali tribe of Seravarayan Hills, Yercaud, Salem district, Tamil Nadu, India, Zoos' Print Journal., 21(4): 2223-2224.

39.Vaidyanathan, D., Salai Senthilkumar, M.S., Sisubalan, N. and Ghouse Basha, M. (2014). Studies on ethnomedicinal plants used by malayali gounder tribals in Pachamalai of Eastern ghats, Tamil Nadu, India, Advances in Applied Sciences Research., 5 (1): 244 - 253.

40.Varsha shelke and Meeta Bhot. (2019). GC-MS analysis and Bio-active compounds in ethanolic extract of leaf and stem of Asclepias curassavica L. Int. J. Pharm., 9(2): 67-70. 